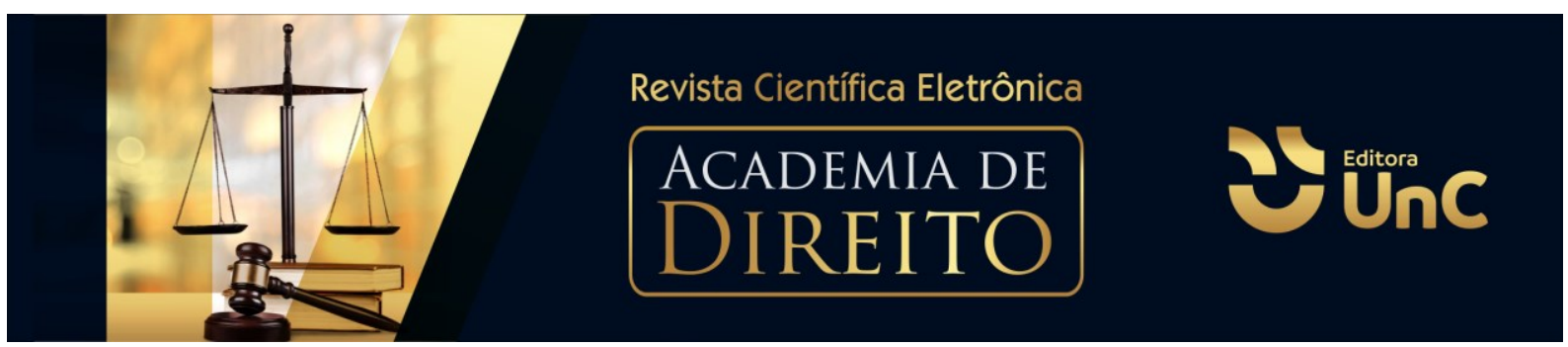

\title{
A INCONSTITUCIONALIDADE DO IMEDIATO CUMPRIMENTO DE PENA APLICADA PELO TRIBUNAL DO JÚRI
}

\section{THE IMMEDIATE UNCONSTITUTIONALITY COMPLIANCE WITH THE PENALTY APPLIED BY THE COURT OF THE JURY}

\author{
Gabrielle Sanchuki Cruz dos Santos ${ }^{1}$ \\ Paulo Silas Taporosky Filho ${ }^{2}$
}

\begin{abstract}
RESUMO
O processo penal brasileiro sofreu algumas alterações com o advento da Lei $n$. $^{\circ}$ 13.964/2019, conhecida como pacote anticrime, reformulando também alguns aspectos do Código de Processo Penal. O resultado dessa grande reforma gerou amplos debates. O objeto do presente trabalho é abordar a inconstitucionalidade do que agora está previsto no artigo 492, inciso I, "e" do Código de Processo Penal, o qual viola expressamente o último posicionamento do SupremoTribunal Federal sobre a execução antecipada da pena. A partir da reforma mencionada, quem for condenado a pena igual ou superior a 15 (quinze) anos de reclusão, deverá ser recolhido à prisão, independentemente de estarem presentes os requisitos da prisão preventiva. Visa-se apresentar os argumentos pelos quais torna referido artigo inconstitucional. Desta forma, como metodologia tem-se a análise do artigo 492, inciso I, "e", do Código de Processo Penal, cumulado com uma análise doutrinária e jurisprudencial acerca do assunto, utilizando-se, assim, o método dedutivo, via revisão bibliográfica, concluindo-se pela inconstitucionalidade do tema abordado.
\end{abstract}

Palavras-Chave: Prisão processual. Júri. Inconstitucionalidade.

\section{ABSTRACT}

The Brazilian criminal process has undergone some changes with the advent of Law n. 13.964/2019, known as the anti-crime package, reformulating some aspects of the Code. The result of this major reform was, in some ways, promising. However, the object of the present work is to address the unconstitutionality of what is provided for in article 492, item I, "e", which expressly violates the Supreme Federal Court's last

\footnotetext{
${ }^{1}$ Acadêmica da $10^{\text {a }}$ fase do curso de Direito da Universidade do Contestado (UnC). Campus Canoinhas. Santa Catarina. Brasil. E-mail: gsanchuki@gmail.com

${ }^{2}$ Mestre em Direito pelo Centro Universitário Internacional (UNINTER); Especialista em Ciências Penais, em Direito Processual Penal e em Filosofia. Pós-graduando (lato sensu) em Teoria Psicanalítica. Professor de Processo Penal na Universidade do Contestado (UnC). Professor de Criminologia no Centro Universitário Internacional (UNINTER). Universidade do Contestado (UnC). Campus Canoinhas. Santa Catarina. Brasil. E-mail: paulosilasfilho@hotmail.com
} 
position on the early execution of the sentence. As from the aforementioned reform, whoever is sentenced to a sentence equal to or greater than 15 (fifteen) years of imprisonment, must be taken to prison, regardless of the requirements of preventive detention being present. The aim is to present the arguments for making the article unconstitutional. In this way, as a methodology we have the analysis of article 492, item I, "e", of the Code of Criminal Procedure, combined with a doctrinal and jurisprudential analysis on the subject, using, thus, the deductive method, concluding that the topic addressed is unconstitutional.

Keywords: Procedural prison. Jury. Unconstitutionality.

\section{INTRODUÇÃO}

A Lei n. ${ }^{\circ} 13.964 / 2019$ promoveu a sanção do chamado pacote anticrime, que estava em discussão no Congresso Nacional desde o primeiro semestre de 2019. Dentre as mudanças trazidas por esta lei, tem-se a introdução no Código de Processo Penal do artigo 492, I, "e", o qual dispõe que nos casos dos crimes submetidos ao Tribunal do Júri, na hipótese de condenação a uma pena igual ou superior a 15 (quinze) anos de reclusão, será determinada a prisão imediata do réu, sem prejuízo da interposição de recursos.

No entanto, esse dispositivo é um dos mais problemáticos inseridos na referida lei, haja vista que é claramente inconstitucional. Isso porque, além de se tratar de uma espécie de prisão que não se amolda a nenhuma das categorias possíveis (prisão pena ou prisão processual), o Supremo Tribunal Federal já se manifestou sobre o tema nas Ações Declaratórias de Constitucionalidade n. 43, 44 e 54, nas quais afirmou que é constitucional o previsto no artigo 283 do Código de Processo Penal, o qual prevê o esgotamento de todas as possibilidades de recurso para o início do cumprimento da pena.

Desta forma, nada justifica tratamento diverso às pessoas condenadas nos crimes que devem ser julgados perante o Tribunal do Júri, sendo que a decisão de prender imediatamente o condenado a pena superior a quinze anos no Tribunal do Júri é uma violação, dentre outros, ao princípio da presunção de inocência.

A presunção de inocência não é apontar que o réu é inocente, mas sim um dever de tratamento, uma vez que o Estado deve tratar o cidadão como se ele inocente fosse, até que se tenha uma sentença penal condenatória transitada em 
julgado. E, ao sancionar mencionado artigo, o legislativo brasileiro esqueceu que o referido princípio é cláusula pétrea.

Por que a diferença de tratamento entre quem é condenado no juízo comum ou pelo Tribunal do Júri? Diante do interesse nessa resposta e nas discussões e divergências acerca do assunto, o presente trabalho aborda os motivos pelos quais o artigo 492, I, "e", do Código de Processo Penal deve ser considerado inconstitucional. Nesse sentido, a temática se delimita no que tange aos problemas inseridos com a aplicação desta norma, utilizando-se da revisão bibliográfica para tanto.

\section{A EXECUÇÃO ANTECIPADA DA PENA E O HC 126.292}

A execução antecipada da pena é uma espécie sui generis de ato prisional, pois não constitui modalidade de flagrante e não se enquadra em qualquer das categorias prisão pena ou prisão processual. É um ato que tolhe a liberdade do acusado quando após a prolação de uma decisão condenatória, mas que se procede antes, porém, do trânsito em julgado. Referido tema envolve grande discussão, bem como atinge diretamente o princípio da presunção de inocência.

A celeuma acerca da temática já havia sido discutida quando da ocasião do julgamento do Habeas Corpus 126.292 pelo Supremo Tribunal Federal, quando na ocasião se estabeleceu a interpretação segundo a qual seria possível dar início ao cumprimento provisório da pena quando esta resultasse da confirmação em segundo grau de sentença penal condenatória, tendo-se aí hipótese de exceção de medida prisional cabível. O que se teve nessa ocasião foi um percalço evidente, uma vez que trágica foi a relativização sofrida pela presunção de inocência, pois a partir de tal entendimento adotado passou a ser possível, na práxis jurisdicional, antecipar a execução da pena quando da confirmação de sentença condenatória em segundo grau, prendendo-se assim o acusado ainda antes de se atingir o trânsito em julgado, pelo que mitigada restava a presunção de inocência - um dos principais basilares do Estado Democrático de Direito.

Foi em fevereiro de 2016, no julgamento do referido habeas corpus, que o Supremo Tribunal Federal passou a admitir a execução antecipada da pena, repristinando entendimento que já havia há muito sido superado. 
Lenio Streck e Rafael Tomaz de Oliveira, em texto produzido anteriormente à mudança da perspectiva adotada pelo Supremo Tribunal Federal noHC 126.292, demonstraram como se dava o entendimento pela Corte Superior acerca da temática da presunção de inocência:

\footnotetext{
Nos últimos anos, o tema da presunção de inocência tem ganhado destaque nos julgamentos do STF. No Plenário, firmou-se o posicionamento de que é inconstitucional a chamada execução antecipada da pena, tendo sido apontada uma possível inconstitucionalidade (não recepção) do art. 637 do CPP, que vedava a atribuição de efeitos suspensivos aos recursos extraordinários interpostos em matéria criminal (STRECK; OLIVEIRA, 2012, p. 62).
}

O equívoco interpretativo nessa mesma toada foi reafirmado no mesmo ano quando do julgamento das liminares das Ações Declaratórias de Constitucionalidade 43 e 44, mantendo-se durante determinado tempo a orientação do Supremo que possibilitava a execução antecipada da pena.

Tempo depois, com o julgamento do habeas corpus do ex-presidente Luis Inácio Lula da Silva, por seis votos a cinco, o Supremonovamente reafirmou a possibilidade da execução antecipada da pena. Neste julgamento, a Ministra Rosa Weber afirmou que, particularmente, era contra a execução antecipada da pena, mas como não estavam julgando as ADC's supracitadas, acabou votando com a maioria, o que tornou um voto bastante polêmico.

Finalmente, em novembro de 2019 foi julgado o mérito das referidas ADCs, quando, por seis votos a cinco, foi decidido pela constitucionalidade do artigo 283 do CPP, interpretação essa passou a vigorar mediante exercício de controle concentrado de constitucionalidade.

A partir disso, é possível afirmar que as modalidades prisionais que comportam espaço no processo penal brasileiro são aquelas que podem ser compreendidas como prisão pena (onde o ato prisional decorre de decisão pena condenatória que transita em julgado) e prisão processual (a qual se trata de decisão em qualquer fase do processo, desde respeitadas suas premissas fundantes, que permite a prisão de alguém por motivo determinado com o fito de salvaguardar o processo).

Desta forma, percebe-se que a decretação de prisão no Tribunal do Júri, nos moldes do artigo 492, inciso I, "e" do Código de Processo Penal, não se enquadra 
em qualquer das modalidades possíveis de prisão, além de violar expressamente o último posicionamento do Supremo Tribunal Federal sobre a execução antecipada da pena, uma vez que a novel causa prisional constitui modalidade dessa peculiar espécie.

Sobre o tema, Pacelli destaca:

\begin{abstract}
O tema é da maior importância, na medida em que a Suprema Corte, no julgamento do HC 126292/2016, alterou radicalmente a sua jurisprudência, por 7 votos a 4, vencidos os Ministros Ricardo Lewandowski, Marco Aurélio, Celso de Mello e Rosa Weber, para assentar novo posicionamento, no sentido de que seria possível a execução provisória da sentença condenatória já a partir do acórdão de segundo grau (2018, p. 628).
\end{abstract}

Se é verdade que, equivocadamente, no Habeas Corpus 126.292/2016 o Supremo Tribunal Federal chegou a possibilitar que 0 acusado iniciasse 0 cumprimento da pena a partir do momento em que a sentença fosse confirmada em segunda instância, há de se evidenciar que, nessa toada de interpretação constitucional, desde o final de 2019 não é mais possível a execução antecipada da pena. Na ocasião do julgamento das já referidas ADCs, estabeleceu-se que a prisão poderá ocorrer apenas após o trânsito em julgado da decisão condenatória, ou seja, depois de esgotadas todas as possibilidades de recurso - sem prejuízo das prisões processuais previstas e possibilitadas pelo ordenamento jurídico, como a prisão preventiva e a prisão temporária. Assim, qualquer prisão que venha a ocorrer antes do trânsito em julgado, precisa ter uma natureza cautelar, isto é, com as razões devidamente fundamentadas acerca de referida prisão, destacando a necessidade de indícios de autoria e a materialidade do delito, além do periculum libertatis, demonstrando que o agente precisa ser preso para a garantia da ordem pública.

Esta decisão baseia-se, principalmente, na literalidade do artigo $5^{\circ}$, inciso LVII, da Constituição Federal, o qual estabelece que ninguém poderá ser considerado culpado antes do trânsito em julgado da sentença condenatória. Prevaleceu, portanto, o princípio da presunção de inocência, através do qual se tem que a insuficiência probatória deve ser benéfica ao réu, isto é, se não houver provas suficientes de quem praticou o crime, o suspeito deverá ser absolvido. A própria Constituição Federal, quando delineada pelo poder constituinte, não se limita a estabelecer que a culpa deve ser provada na forma da lei, uma vez que especifica 
que isto só pode ocorrer quando do "trânsito em julgado de sentença penal condenatória" (CF/88 art. 5, LVII).

Diante do até aqui exposto, insta salientar que o HC 126.292 pode ser uma possível origem do problema tratado no presente artigo, qual seja, a prisão obrigatória no Tribunal do Júri, razão pela qual, antes do apontamento da questão nevrálgica que reside no tema, faz-se necessário abordar a ausência de uma episteme que dê amparo à qualquer figura de prisão obrigatória.

\section{O LIMBO DA ESPÉCIE DA PRISÃO ANTECIPADA}

Conforme brevemente já destacado, duas são as espécies de prisão que se pode apontar como legítimas no âmbito do processo penal, a saber, a prisão pena, vinculada à sentença penal condenatoria irrecorrível para que possa surtir seus efetios, e a prisão processo, cabível quando amparada pelas hipóteses concretas previstas no ordenamento jurídico processual.

A distinção de tais modalidades se faz necessária tanto para evidenciar a inexistência com aporte fundante de qualquer outro tipo, quanto para destacar a cautela sobre a confusão que pode ser feita com relação a ambas. Nesse sentido, necessário ressaltar que "o erro de premissa que considera o processo penal como adjetivo do direito penal acaba por permitir a transposição de teorias inerentes à pena [categoria própria de direito material] para atos puramente processuais, como por exemplo, a prisão cautelar" (MINAGÉ, 2017, p. 152). Assim, não devem ser confundidas tais modalidade prisionais, evitando-se falar, por exemplo, nos fins da pena como fundamento quando a discussão girar em torno de espécie de prisão processual - como é o caso da prisão preventiva ou temporária, pois "as funções de prevenção geral e especial e retribuição são exclusivas de uma pena, que supõe um processo judicial válido e uma sentença transitada em julgado. Jamais tais funções podem ser buscadas na via cautelar" (LOPES JR., 2012, p. 841).

No caso da prisão obrigatória que decorre de execução antecipada da pena, qualquer seja o pseudofundamento pretensamente legitimante, tem-se que não se amolda ao tipo prisão pena, pois a possibilidade de interposição recursal se encontra ainda como medida presente. De igual modo não há que se falar em espécie de prisão processual, pois dada a natureza de cautelaridade que pressupõe essa 
categoria prisional, tem-se que há de se observar o preenchimento dos requisitos que fundam cada tipo dessa - prisão preventiva ou prisão temporária -, requisitos esses estipulados em lei, o que não é o caso de qualquer espécie de prisão cuja incidência seja obrigatória quando atendido mero pressuposto objetivo, pois a inconstitucionalidade em assim ser é evidente.

Não há, portanto, substrato normativo que possibilite se falar em qualquer espécie de prisão que fuja das modalidades realmente legítimas. Ou se tem prisão pena ou se tem processual. Em se tratando de medida de restrição cautelar que tolha a liberdade do individuo, só se terá efetivo grau de legitimidade em tal medida caso observa a principiologia inerente no âmbito das cautelares, uma vez que qualquer hipótese de restrição de liberdade de alguém que não atenda a tudo o que tal gravosa medida acarreta, estar-se-á a falar e tratar de medida ilegítima por inobservância da base constitucional que deve fundamentar e erigir um processo penal democrático e justo.

Nos dizeres de Gomes:

\begin{abstract}
Podemos perceber que princípio entram em conflito diretamente no caso das prisões cautelares - direito à liberdade e dignidade da pessoa humana vs o interesse público através da garantia da ordem pública -, pensamos que não é difícil acreditar que neste caso os princípios inerentes às garantias individuais de todo o cidadão devem ter um peso maior que o interesse público, afinal teremos que recorrer à máxima que é melhor um culpado solto do que um inocente preso (GOMES, 2018, p. 72).
\end{abstract}

Assim, há de se ter a devida cautela ao tratar das possibilidade prisionais, não devendo se abrir qualquer espaço para que jargões inflamados pelos discursos punitivistas tomem conta do ambiente, uma vez que é a liberdade que está em jogo quando da jurisdição posta em prática na seara penal. Daí que a observação se faz necessária com relação ao que se diz (e quem diz) no cenário do processo penal, evitando-se que o processo penal metafísico produza seus deletérios efetios, assim explicado por André Peixoto de Souza:

\footnotetext{
O choque semântico que suscita confissão judiciária (decretos prisionais em nome da segurança/ordem pública) adentra a uma espécie de senso comum jurídico e se repete vertiginosamente enquanto verdade indefensável e imutável, transmutando-se, por fim, na gloriosa metafísica do processo penal, sobre a qual reside a imperiosa crença judiciária, ministerial, policialesca, midiática e popular, nessa ordem (SOUZA, 2018).
} 
É por assim (não) ser que se diz que a prisão antecipada, de qualquer espécie, não encontra lá, nem cá, estando assim situada numa espécie de limbo sobre o qual não é possível dizer (e aplicar).

\section{A INCONSTITUCIONALIDADE DO ARTIGO 492, I, "e", DO CÓDIGO DE PROCESSO PENAL}

Exemplo dessa "nova" e ilegítima espécie de prisão antecipada é aquela que se opera no Júri em hipótese regrada após o advento da "Lei Anticrime" - que desde quando ainda era um (diferente) projeto já apontava para os seus efeitos de manutenção da estrutura inquisitória, deixando assim "o Brasil de braços com o atraso" e consolidando e ampliando "as inconstitucionalidades de todo indesejadas" (COUTINHO et al, 2019). Apesar de o STF ter dado entendimento diverso sobre a execução antecipada da pena, a questão está agora aberta no tocante ao Tribunal do Júri, pois o artigo 492 do Código de Processo Penal, na redação dada pela Lei n. $13.964 / 2019$, dispõe que caso o réu seja condenado a pena igual ou superior a 15 (quinze) anos, ele já começará a cumprir antecipadamente sua sanção. Além disso, referido artigo alterou o efeito do recurso de apelação nestes casos, ou seja, o recurso de apelação não é suspensivo, obrigando o sujeito a ficar detido até decisão superior.

Inicialmente, insta salientar que o Júri possui um processo bifásico, sendo que na primeira fase o juiz submete ou não o réu para um plenário de julgamento perante os jurados e a segunda fase é a decisão proferida pelo colegiado, que é composto pelos jurados. A Constituição Federal prevê que a decisão dos jurados é soberana, não sendo passível de reforma. Acontece que o Código de Processo Penal traz hipóteses que invalidariam a decisão, pois apesar de haver a soberania da decisão dos jurados, essa também é passível de erros judiciais. De todo modo, deve-se atentar que essas duas fases no Tribunal o Júri ocorrem em primeira instância. Deste modo, o que se tem é uma clara violação à presunção de inocência, além do "contrassenso a lógica estabelecida pelo novel art. 283 do CPP, que em consonância com o art. $5^{\circ}, \mathrm{LVII}, \mathrm{CF} / 88$, impôs o trânsito em julgado como marco inicial para o início do cumprimento da pena" (LIMA, 2020). 
A partir da decisão proferida pelo Tribunal do Júri,é ainda cabível recurso de apelação, onde a defesa poderá alegar qualquer nulidade ocorrida durante o julgamento ou quando os jurados decidem de forma contrária às provas dos autos, conforme dispõe o artigo 593 do Código de Processo Penal.

O princípio da soberania dos veredictos consiste na impossibilidade de reforma da decisão tomada pelo conselho de sentença, pelo órgão revisional. $\mathrm{O}$ Tribunal de Justiça não poderá, é certo, diante da análise do recurso de apelação, da acusação ou da defesa, reformar a decisão proferida pelos jurados. Porém, isso não significa dizer que o duplo grau de jurisdição deixa de ser observado nas decisões prolatadas no Tribunal do Júri. Há a possibilidade do reconhecimento de nulidade quando houver uma decisão manifestamente contrária às provas dos autos, a fim de possibilitar a submissão da pessoa já julgada, a novo julgamento. Por isso que antecipar a pena do acusado, restringindo seu direito ao duplo grau de jurisdição, é inadmissível. Tanto a pena quanto o próprio julgamento podem ser passíveis de alteração, dando outro rumo à vida da pessoa que está sendo julgada, sendo "evidente que a antecipação no cumprimento da pena traz prejuízos incontornáveis ao indivíduo presumidamente inocente, que tem a sua liberdade suprimida, antes de ser considerado formalmente culpado" (LIMA, 2020).

Nesse sentido, a jurissprudência é norteada pelos princípios que podem ser extraídos do julgado que segue:

DIREITO PROCESSUAL PENAL. RECURSO EM HABEAS CORPUS.
APELAÇÃO. SOBERANIA DOS VEREDICTOS DO TRIBUNAL DO JÚRI.
DECISÃO MANIFESTAMENTE CONTRÁRIA A PROVA DOS AUTOS.
IMPROVIMENTO. 1. A questão central, neste recurso ordinário, diz respeito
à possível violação à garantia da soberania dos veredictos do tribunal do júri
no julgamento do recurso de apelação da acusação, nos termos do art. 593,
III, b, do Código de Processo Penal. 2 . A soberania dos veredictos do
tribunal do júri não é absoluta, submetendo-se ao controle do juízo ad
quem, tal como disciplina o art. 593, III, d, do Código de Processo
Penal. O fundamento do voto do relator da apelação foi exatamente o de
que o julgamento pelo corpo dos jurados se realizou de modo arbitrário,
sem obedecer parâmetros respaldados nos elementos de prova constantes
dos autos. 3 . Caso os jurados alcancem uma conclusão
manifestamente contrária à prova produzida durante a instrução
criminal e, que portanto, consta dos autos, o error in procedendo
deverá ser corrigido pelo Tribunal de Justiça. 4 . Esta Corte tem
considerado não haver afronta à norma constitucional que assegura a
soberania dos veredictos do tribunal do júri no julgamento pelo
tribunal ad quem que anula a decisão do júri sob o fundamento de que
ela se deu de modo contrário à prova dos autos (HC $73.721 / R J$, rel. Min.
Carlos Velloso, DJ 14.11 .96 ; HC $74.562 / S P$, rel. Min. Ilmar Galvão, DJ Carlos Velloso, DJ 14.11.96; HC 74.562/SP, rel. Min. Ilmar Galvão, DJ 
06.12.96; HC 82.050/MS, rel. Min. Maurício Correa, DJ 21.03.03). 5. O sistema recursal relativo às decisões tomadas pelo tribunal do júri é perfeitamente compatível com a norma constitucional que assegura a soberania dos veredictos (HC 66.954/SP, rel. Min. Moreira Alves, DJ 05.05.89; HC 68.658/SP, rel. Min. Celso de Mello, RTJ 139:891, entre outros). 6. O juízo de cassação da decisão do tribunal do júri, de competência do órgão de $2^{\circ}$ grau do Poder Judiciário (da justiça federal ou das justiças estaduais), representa importante medida que visa impedir o arbítrio, harmonizando-se com a natureza essencialmente democrática da própria instituição do júri. 7 . O habeas corpus não pode ser utilizado, em regra, como sucedâneo de revisão criminal. 8. Recurso ordinário improvido. (RHC 93248, Relator(a): ELLEN GRACIE, Segunda Turma, julgado em 05/08/2008, DJe-157 DIVULG 21-08-2008 PUBLIC 22-08-2008 EMENT VOL-02329-03 PP-00486). (grifo nosso)

Ao possibilitar a prisão antecipada no âmbito do júri, tem-se uam espécie de inversão:utiliza-se do argumento da soberania dos veredictos para restringir outras garantias, como a possibilidade de recurso que o acusado tem, assim como o princípio da presunção de inocência.

Adentrando na inconstitucionalidade da prisão obrigatória do júri para condenação superior a quinze anos, tem-se que"cuida-se de uma norma sem base lógica. O condenado a 14 anos e 11 meses poderia ficar em liberdade, mas o que foi apenado a 15 anos seria preso. O critério deve ser uniforme, sempre" (NUCCI, 2020, p. 88).

Esse critério do qual se diz deve ser observado numa decisão amparada e bem fundamentada, o que significa dizer que a interpretação merece esmero no que tange à observância da correta aplicação do direito ao caso concreto, sendo possível somente quando o amparo jurídico for realente legítimo. Isso porque "interpretar [...] não é uma carta em branco que se dá ao intérprete, seja ele qual for, do ministro do STF ao mais humilde dos servidores públicos" (COUTINHO, 2018, p. 110).

Desta forma, verifica-se mais um motivo pelo qual a existência de tamanho erro ao decretar a prisão do réu ao final da Sessão, em caso de condenação superior a quinze anos, já que sua sentença foi dada sem motivação e com possibilidade de decisões superiores. Sobre o assunto, leciona Guilherme de Souza Nucci:

Jurados decidem de acordo com a sua consciência e não segundo a lei. Aliás, esse é o juramento que fazem (art. 472, CPP), em que há a promessa 
de seguir a consciência e a justiça, mas não as normas escritas e muito menos os julgados do País. (NUCCl, 2008, p. 32)

Todos sabemos que um crime contra a vida, cuja competência é exclusiva do Tribunal do Júri, é sempre um fato lamentoso. O que não se admite é que haja um Estado vingador, pois o Poder Judiciário não possui função de vingança, mas sim deve aplicar uma pena adequada ao crime praticado e que seja cumprida da mesma forma que os demais crimes.

Destaca-se, ainda, que é colocada a pena superior a 15 (quinze) anos para que haja a execução antecipada da pena, sendo que quem quantitativa a pena é o juiz e não os jurados, de modo que por determinada lógica peculiar a execução antecipada da pena não violaria a soberania dos veredictos. Além disso, há de se levar em conta hipótese de, em fase recursal cuja discussão verse sobre o quantum da pena, ocorrer a diminuição da penalidade quando aplicada em excesso. Então, se o réu que foi condenado a 15 (quinze) anos de reclusão e já está cumprindo a pena de forma antecipada, tem sua pena diminuída no Tribunal, já não precisaria mais haver aquela execução antecipada. Essa prisão ilegal retira toda a proteção que é prevista pela Constituição Federal.

O princípio da presunção de inocência, chamado também de princípio da não culpabilidade, é a base do processo penal, e no Brasil ele está consagrado no artigo $5^{\circ}$, inciso LVII, da Constituição Federal. Possui extrema relevância no ordenamento jurídico, pois tal princípio deve representar" mais que mera presunção de inocência: o réu encontra-se em estado de inocência, já que não é considerado culpado enquanto não verificado o trânsito em julgado" (ROSA, 2016, p. 301).

Somente em um estado autoritário é possível admitir que se prenda alguém por uma simples suspeita da prática de um crime - ou ainda onde se tenha previsão normativa de espécie de prisão obrigatória que prescinda de qualquer outro tipo de análise para além do quantum de pena (recorrível) imposta ao sujeito que presumidamente inocente.

Do princípio da presunção de inocência derivam duas regras fundamentais: a regra probatória, segundo a qual cabe à parte acusadora a função de demonstrar e provar a culpabilidade do acusado, e a regra de tratamento, a qual prevê que 
ninguém pode ser considerado culpado antes da sentença com trânsito em julgado, impedindo qualquer antecipação de juízo condenatório.

Nesse sentido, explica Nucci:

\begin{abstract}
A presunção de inocência gera os seguintes efeitos práticos: (a) o ônus da prova pertence à acusação, bastando ao réu negar a prática da imputação ou, simplesmente, invocar o seu direito ao silêncio; (b) as medidas cautelares restritivas da liberdade, do patrimônio ou da intimidade devem ser decretadas com zelo e rigor, somente em situações efetivamente necessárias.(2019, p. 3)
\end{abstract}

Ainda, no âmbito jurisprudencial:

APELAÇÃO CRIMINAL - RÉU SOLTO - CRIME ESTELIONATO

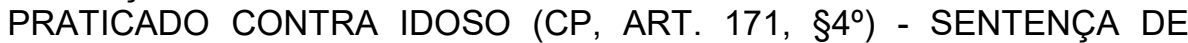
PARCIAL PROCEDÊNCIA - CONDENAÇÃO PELO CRIME TIPIFICADO NO ART. 171, CAPUT, DO CP. RECURSO DA DEFESA. ABSOLVIÇÃO TESE DE INSUFICIÊNCIA DE PROVAS - ACOLHIMENTO - TERMO DE RECONHECIMENTO QUE APONTA PESSOA DISTINTA DO RÉU COMO AUTOR DO FATO - FRAGILIDADE DO CONJUNTO PROBATÓRIO APLICABILIDADE DO PRINCÍPIO DO IN DUBIO PRO REO - ABSOLVIÇÃO MANTIDA - EXEGESE DO ART. 386, VII, DO CPP. "A falta de elementos de convicção que demonstrem ligação do acusado com o fato delituoso podem gerar, no julgador, dúvida acerca do nexo causal. Assim, deve ser invocado o princípio do in dubio pro reo, devendo o fato ser resolvido em favor do imputado, uma vez que a culpa penal deve restar plenamente comprovada, em razão da presunção de inocência. Isso porque, a garantia da liberdade deve prevalecer sobre a pretensão punitiva do Estado, princípio este que está implícito no inciso VII do art. 386 do Código de Processo Penal" (STJ, Min. Joel Ilan Paciornik). RECURSO CONHECIDO E PROVIDO. (TJSC, Apelação Criminal n. 000753184.2016.8.24.0018, de Chapecó, rel. Des. Getúlio Corrêa, Terceira Câmara Criminal, j. 14-04-2020). (grifo nosso)

Deste modo, tem-se que o princípio da presunção de inocência deve proteger o acusado contra a ineficiência e abuso da atividade estatal, atuando como norma de controle das atividades do Poder Público, garantindo uma investigação e eventual condenação fundada em provas precisas. Havendo dúvida ou insuficiência de provas, não há que se falar com condenação ou qualquer espécie de prisão obrigatória.

A presunção de inocência é um dever de tratamento, pelo que o Estado deve tratar o cidadão como se ele inocente fosse, até que se tenha uma sentença penal condenatória transitada em julgado. 
Destaca-se ainda a previsão normativa daquilo que dispõe o artigo 283 do Código de Processo Penal: "Ninguém poderá ser preso senão em flagrante delito ou por ordem escrita e fundamentada da autoridade judiciária competente, em decorrência de prisão cautelar ou em virtude de condenação criminal transitada em julgado".

Referido dispositivo prevê expressamente que apenas se admite prender alguém em caso de flagrante delito, por ordem escrita e fundamentada por autoridade judiciária, nos casos de prisão cautelar ou condenação transitada em julgado. Não há qualquer previsão no sentido de possibilitar prisão outra, tal como aquela prevista na questionada previsão com relação à segregação antecipada no âmbito do júri.

Conforme mencionado anteriormente, por meio das Ações Declaratórias de Constitucionalidade 43 e 44, o artigo 283 do Código de Processo Penal foi declarado constitucional pelo Supremo Tribunal Federal. Ao se aplicar o imediato cumprimento de pena nas condenações proferidas pelo Tribunal do Júri, tal como no dispositivo trazido pela lei anticrime, essa normativa deixa de ser considerada.

Assim, a regra é que apenas haja a execução da pena com o trânsito em julgado da condenação criminal, e não com uma decisão de primeiro grau que ainda não teve seu trânsito em julgado fora das hipóteses permitidas no que tange às prisões de caráter cautelar. O que se tem assim é uma clara violação aos direitos e garantias fundamentais previstos na Constituição Federal quando se admite a prisão imediata após a decisão do Tribunal do Júri.

Urge salientar que o tema, dada a sua relevância, deu origem ao Recurso Extraordinário 1.235.340, no qual foi reconhecida a repercussão gral da matéria, onde se passou a questionar a (in)constitucionalidade do imediato cumprimento de pena aplicada pelo Tribunal do Júri. Figurando como relator o Ministro Luis Roberto Barroso, o recurso foi interposto pelo Ministério Público de Santa Catarina contra acórdão do Superior Tribunal de Justiça que não admitiu o imediato cumprimento da pena aplicada pelo Tribunal do Júri. A alegação recursal aponta que a tese do STJ contraria o princípio da soberania dos veredictos, arrazoando que a decisão não poderia ser revista pelo Tribunal de apelação.

O Ministro relator votou pela constitucionalidade da prisão imediata no Tribunal do Júri. O Ministro Dias Toffoli votou no mesmo, assim aduzindo: 
Meu ponto de vista sobre a matéria é conhecido por todos, já que no final de 2019 , ao concluirmos o julgamento das ADC'sns $^{\circ} 43,44$ e 54 , a respeito da execução provisória da pena após julgamento em segundo grau, reiterei me entendimento no tocante à possibilidade do cumprimento imediato da pena após decisão do tribunal do júri. (RE 1235340 / SC, p. 2)

Por outro lado, o Ministro Gilmar Mendes divergiu dos Ministros que votaram, afirmando:

\begin{abstract}
Nesse sentido, concluiu-se no julgamento das ADCs 43, 44 e 54 que a execução provisória da pena não é admitida nos termos da Constituição de 1988 e do Código de Processo Penal. Desse modo, a imposição de uma prisão antes do trânsito em julgado da condenação somente pode se justificar se houver motivação concreta que embase a decretação de prisão preventiva.

Diante disso, não há qualquer motivo legítimo para que tal precedente não se aplique aos casos julgados por jurados. Permitir a execução imediata da condenação proferida em primeiro grau pelos jurados é ainda mais gravoso do que a posição reformada pelo Plenário nos julgamentos das ADCs 43, 44 e 54, o que caracteriza evidente violação à presunção de inocência. (RE 1235340 / SC, p. 19)
\end{abstract}

No entanto, o Ministro Ricardo Lewandowski pediu vista nos autos, interrompendo o julgamento.

Resta o aguardar pela manifestação do Supremo no que diz respeito à matéria ora discutida. De todo modo, é possível desde já destacar o fato de que a previsão sobre a qual recai a atenção no presente escrito constitui afronta aos princípios constitucionais que erigem um processo penal verdadeiramente democrático. A antecipação da prisão sem a presença dos requisitos necessários para decretar a prisão cautelar é claramente inconstitucional.

\title{
5 CONCLUSÃO
}

É possível vislumbrar, a partir das questões trazidas no presente escrito, que é claramente perceptível a inconstitucionalidade do artigo 492, I, "e", do Código de Processo Penal.

O caminho trilhado pelo Brasil no âmbito de sua política criminal está voltado ao combate simbólico da criminalidade a qualquer custo, preocupado apenas em satisfazer o clamor público, deixando de lado os direitos que deveriam ser garantidos a todos os cidadãos. 
Esse fenômeno de criação de leis mais rigorosas gera à sociedade uma falsa sensação de justiça, convencendo a população de que o Estado está preocupado com a criminalidade existente. Ocorre que essa ilusão serve apenas para mascarar que o Brasil não está preocupado com uma política criminal definida, com bases sólidas e estruturadas. Vale mais o imediatismo populista penal, pois embasado num conforto epistêmico enfadonha que tapa os olhos para toda a problemática que reside nas ciências penais em geral.

O argumento de que o princípio da soberania dos veredictos deve prevalecer ante o princípio da presunção da inocência é outra maneira de tentar aliciar a sociedade de que a prisão imediata no Tribunal do Júri é constitucional. Isso porque os direitos do conselho de sentença continuarão garantidos. Quem quantifica a pena é o magistrado, não os jurados. Já o princípio da presunção da inocência está sendo visivelmente violado. No momento em que a prisão antecipada é admitida, o princípio da presunção da inocência está sendo relativizado para prevalecer um princípio que não é individual, ou seja, a garantia da malograda e intraduzível ordem pública.

Verifica-se que apesar de hodiernamente o Supremo Tribunal Federal não mais admitir a execução antecipada da pena, houve visível alteração com a Lei n. $13.964 / 2019$ ao instituir a possibilidade de prisão em plenário contra o acusado nas hipóteses de a pena estabelecida ser igual ou superior a 15 anos, sendo que a decisão proferida no HC 126.292 pode ser uma das origens desse problema.

Apesar de a única leitura válida de um processo penal constitucional é aquela em que a prisão somente é cabível nos casos em que há o atendimento do caráter da cautelaridade processual penal, o novo artigo 492, inciso I, "e" do Código de Processo Penal volta a pregar a ideia de que a prisão obrigatória seria instrumentlo legítimo para combanter a impunidade a todo e qualquer custo.

A problemática do disposto neste artigo está em discussão no Supremo Tribunal Federal, por meio do Recurso Extraordinário n. 1.235.340, questionando-se a (in)constitucionalidade do imediato cumprimento de pena aplicada na Sessão do Tribunal do Júri quanto ultrapassado o quantum determinado da reprimenda estatal. Seja qual for o resultado que se estabelecerá na interpretação do Supremo sobre a questão, pela matriz de um processo penal democrático e justo, leitura possível 
outra não há que não a de reconhecer a inconstitucionalidade do dispositivo. A prisão obrigatória em processo penal é notoriamente inconstitucional.

\section{REFERÊNCIAS}

AVENA, Norberto. Processo penal. 11.ed. Rio de Janeiro: Forense, 2019.

BRASIL. Constituição Federal de 1988, de 05 de outubro de 1988. Constituição da República Federativa do Brasil. Diário Oficial da União, Brasília, DF, nº 191-A de 05 de outubro de 1988.

BRASIL. Código de Processo Penal. Decreto lei $n^{\circ} 3.689$, de 03 de outubro de 1941. Disponível em: http://www.planalto.gov.br/CCIVIL/Decreto-Lei/Del3689.htm.

COUTINHO, Jacinto Nelson de Miranda. Observações sobre os sistemas processuais penais. Curitiba: Observatório da Mentalidade Inquisitória, 2018.

COUTINHO, Jacinto Nelson de Miranda et al. Do projeto de reforma do CPP ao projeto de lei "anticrime"; mirando a Constituição. CONJUR. Disponível em: https://www.conjur.com.br/2019-abr-12/limite-penal-projeto-reforma-cppao-projetolei-anticrime. Acesso em: 05 maio 2020.

DELMANTO JUNIOR, Roberto. Liberdade e prisão no processo penal: as modalidades de prisão provisória e seu prazo de duração. São Paulo: Saraiva, 2019.

GOMES, Jefferson de Carvalho. A criminalização na sociedade do espetáculo: aportes hermenêuticos para a contenção do ativismo judicial. 2018. Dissertação (Mestrado em Direito) - Universidade Católica de Petrópolis, 2018.

LIMA, Daniel. Lei $n^{\circ}$ 13.964/19 e a execução antecipada da sentença condenatória no plenário do júri. Canal Ciências Criminais. Disponível em:

https://canalcienciascriminais.com.br/lei-n-13-964-19-e-a-execucao-antecipada-dasentenca-condenatoria/. Acesso em: 05 maio 2020.

LOPES JR., Aury. Direito processual penal. 9.ed. São Paulo: Saraiva, 2012.

MENDES, Soraia da Rosa; MARTÍNEZ, Ana Maria. Pacote anticrime: comentários críticos à Lei 13.964/2019. São Paulo: Atlas, 2020.

MINAGÉ, Thiago M. Prisões e medidas cautelares à luz da constituição: o contraditório como significante estruturante do processo penal. 4.ed. Florianópolis: Empório do Direito, 2017

NUCCI, Guilherme de Souza. Pacote anticrime comentado. São Paulo: Editora Forense, 2020. 
NUCCI. Tribunal do júri. São Paulo: Editora Revista dos Tribunais, 2008.

PACELLI, Eugenio. Curso de processo penal. 22.ed. São Paulo: Atlas, 2018.

ROSA, Alexandre Morais da. Guia compacto do processo penal conforme a teoria dos jogos. 3.ed. Florianópolis: Empório do Direito, 2016

SOUZA, André Peixoto de. Ordem pública e prisão preventiva. Disponível em: $<$ https://canalcienciascriminais.com.br/ordem-publica-prisao-preventiva/>. Acesso em: 05 jul. 2020

STRECK, Lenio Luiz. OLIVEIRA, Rafael Tomaz de. O que é isto: as garantias processuais penais? Porto Alegre: Livraria do Advogado Editora, 2012.

TAVORA, Nestor; ALENCAR, Rosmar Rodrigues. Curso de direito processual penal. 13.ed. Salvador: Juspodivm, 2018.

Artigo recebido em: 07/07/2020

Artigo aceito em: 04/08/2020

Artigo publicado em: 12/08/2020 